\title{
Perbandingan Kemampuan Konsentrasi Belajar Setelah Mendengar Al-Qur'an: Antara Murattal dan Tilawah
}

\author{
Emir Surya Kautsar ${ }^{1}$, Ilyas Ismail ${ }^{2}$, Eka Damayanti $^{3}$, La Ode Ismail \\ Ahmad $^{4}$ Jamilah $^{5}$ \\ Universitas Islam Negeri Alauddin Makassar, Indonesia \\ 1emirkautsar700@gmail.com, 2ilyas.ismail@uin-alauddin.ac.id, 3eka.damayanti@uin- \\ alauddin.ac.id, ${ }^{4}$ laode.ismail@uin-alauddin.ac.id, 5jamilah@uin-alauddin.ac.id
}

DOI: $10.29240 /$ alquds.v4i1.1254

Submitted: 2019-12-03| Revised: 2020-03-28 |Accepted: 2020-04-15

\begin{abstract}
This study aimed at determining the differences in learning concentration ability between the students who listened to the murattal of Qur'an and those who listened to the recitation of Qur'an. This study was a comparative study with an experimental approach using two-group pretest-posttest design. There were two experimental classes, and they consisted of fifteen students each. The first experimental class was given amurattalaudio of the Qur'an as the intervention, and the second experimental class was given an audio recitation of the Qur'an as the intervention. The data collection instrument used in this study was the concentration ability tests which were developed and referenced from the Employee Aptitude Survey (EAS) test and consisted of 5 sub-tests namely word fluency, verbal comprehension, verbal classification, visual space speed and accuracy test, and understanding of reading test. The result obtained from the two groups based on t test demonstrated sig. (2-tailed) $0.018<\alpha$ 0.05.This showed that there was a significant difference between the students who listened to the murattal of the Qur'an and those who listened to the recitation of the Qur'an. It seems that Qur'anic recitation treatment is more effective in increasing learning concentration.
\end{abstract}

Keywords: Learning Concentration; Murattal of the Qur'an; Recitation of the Qur'an

Abstrak. Penelitian ini bertujuan untuk mengetahui perbedaan kemampuan konsentrasi belajar antara mahasiswa yang diperdengarkan murattal Al-Qur'an dengan tilawah AlQur'an. Penelitian ini merupakan jenis penelitian komparatif dengan pendekatan eksperimental menggunakan desain two group pre and post test design dengan sampel penelitian sebanyak lima belas orang. Pada kelas eksperimen satu yang diberikan perlakuan berupa intervensi audio murattal Al-Qur'an dan kelas eksperimen dua yang diberikan perlakuan berupa intervensi audio tilawah Al-Qur,an. Instrumen pengumpulan data yang digunakan berupa tes kemampuan konsentrasi yang dikembangkan dan dirujuk dari tes Employee Aptitude Survey (EAS) dan terdiri atas 5 sub 
tes yakni subtes word fluency, verbal comprehension, verbal classification, visual space speed and accuracy test, dan understanding of reading test. Hasil penelitian yang diperoleh pada kedua kelompok tersebut berdasarkan hasil uji t diperoleh nilai sig.(2-tailed) $0,018<\alpha 0,05$, hal ini menunjukkan bahwa terdapat perbedaan yang signifikan antara kemampuan konsentrasi belajar mahasiswa yang diperdengarkan audio murattal Al-Qur'an dan audio tilawah Al-Qur'an. Perlakuan yang lebih efektif meningkatkan konsentrasi belajar adalah tilawah Al-Qur'an.

Kata Kunci: Konsentrasi Belajar; Murattal Al-Qur'an; Tilawah Al-Qur'an

\section{Pendahuluan}

Proses belajar terjadi dalam urutan tahapan peristiwa yang meliputi, tahap perhatian (attention phase), tahap penyimpanan dalam ingatan (retention phase), tahap reproduksi (reproduction phase), dan tahap motivasi (motivation phase). Proses belajar dapat terjadi apabila tahap-tahap tersebut diikuti sesuai dengan urutannya. Menurut Syah ${ }^{1}$ agar proses belajar yang dilakukan peserta didik dapat berhasil dengan baik maka diperlukan adanya perhatian (attention) karena perhatian adalah suatu tahap yang harus ada dalam tiap proses belajar.

Perhatian peserta didik yang terfokus (selective attention) akan mempercepat terjadinya proses pembelajaran. Apabila peserta didik telah terfokus pada satu informasi maka informasi tersebut akan sedikit mendapat gangguan dari informasi lain namun sebaliknya apabila peserta didik terdistraksi oleh suatu informasi pada saat proses pembelajaran berlangsung maka fokusnya akan terganggu dan perhatiannya akan terpecah (divided attention) sehingga merusak atau menghilangkannya informasi yang telah disampaikan oleh pendidik. Hal ini terjadi karena adanya proses asosiasi neuron yang saling berkompetisi dan melemahkan sehingga informasi yang ditangkap tidak utuh dan cenderung terjadi miskonsepsi pada pembelajaran yang sedang dipelajarinya. Kemampuan untuk mempertahankan perhatian atau fokus tersebut disebut konsentrasi. $^{2}$

Pada pembelajaran Biologi seringkali peserta didik mengalami pikiran bercabang (duplikasi) dan mengalami kesulitan dalam memahami atau mengingat materi yang diajarkan sehingga membutuhkan kesiapan belajar yang baik. Kondisi otak yang siap dalam menerima pembelajaran yakni pada kondisi gelombang otak berada pada zona alfa karena pada kondisi tersebut merupakan kondisi paling cemerlang dalam proses berpikir seseorang. Kondisi ini dikatakan sebagai kondisi paling baik untuk belajar sebab neuron (sel saraf) sedang berada

${ }^{1}$ Muhibbin Syah, Psikologi Belajar (Jakarta: Rajawali press, 2009), 53.

2 Very Julianto, Rizki Putri Dzulqaidah, and Siti Nurina Salsabila, "Pengaruh Mendengarkan Murattal Al Quran Terhadap Peningkatan Kemampuan Konsentrasi," Psympathic : Jurnal Ilmiah Psikologi 1, no. 2 (2014): 120-29, doi:10.15575/psy.v1i2.473. 
dalam suatu harmoni (keseimbangan). ${ }^{3}$ Dalam kaitannya dengan kemampuan mengingat, ternyata terdapat relevansi antara membaca dan mendengar ayat $\mathrm{Al}$ Qur'an dengan memori. Pelafalan ayat Al-Qur'an merangsang generasi gelombang alfa sehingga suasana menjadi lebih santai dan memungkinkan individu untuk belajar dalam keadaan yang tenang dan mengambil informasi yang dibutuhkan untuk pemecahan masalah. ${ }^{4}$

Peneliti melakukan pilot study pada tanggal 19 Agustus 2019 untuk melihat kemampuan konsentrasi pada 20 mahasiswa pendidikan Biologi yang dipilih secara random. Peneliti memberikan tes untuk mengukur kemampuan konsentrasi. Tes tersebut dirujuk dari tes Employee Aptitude Survey (EAS). Hasil penelitian awal menunjukkan mayoritas responden berada dalam kategori konsentrasi rendah. Dari hasil wawancara diketahui bahwa 15 dari 20 responden menyatakan bahwa resitasi bacaan Al-Qur'an dapat membantu mereka untuk lebih rileks dan mempertahankan konsentrasi dengan lebih lama sementara yang lain menyatakan bahwa mereka membutuhkan kondisi yang tenang untuk berkonsentrasi meskipun selama ini penggunaan audio murattal dan tilawah AlQur'an dengan tujuan untuk meningkatkan daya tahan konsentrasi melalui pengkondisian gelombang otak dalam zona alfa secara intensif belum pernah diterapkan dalam proses pembelajaran Biologi.

Mendengarkan Al-Qur'an baik dalam bentuk murattal maupun tilawah adalah metode secara nonfarmakologis dapat meningkatkan konsentrasi belajar sebab treatment tersebut memiliki andil untuk menciptakan sebuah sensasi yang dapat mempengaruhi respon fisiologis dan psikologis seseorang berupa menurunkan ketegangan, kecemasan, kadar kortisol (hormon yang dihasilkan ketika stress), mengaktifkan hormon endorphin (hormon yang dihasilkan saat sedang bahagia), memperbaiki sistem kimia tubuh dan mengkondisikan gelombang otak pada zona tertentu yang akan bermuara pada peningkatan kemampuan konsentrasi. ${ }^{5} \mathrm{Al}$-Qur'an sebagai teks agama mempunyai dimensi estetika $^{6}$. Gaya recital Al-Qur'an diantaranya terdiri atas gaya bacaan murattal

3 Munif Chatib, Sekolahnya Manusia: Sekolah Berbasis Multipe Intelligences Di Indonesia (Bandung: Kaifa PT Mizan Pustaka, 2012), 90.

${ }^{4}$ Norsiah Fauzan and Nurul Amira Abidin, "The Effects of Neurotherapy (NFT) Using Ayatul Kursi as Stimulus on Memory Performance," Journal of Isamic, Social, Economic and Development 2, no. 4 (2017): 22-31.

${ }^{5}$ Rizem Aizid, Tartil Al-Qur'an Untuk Kecerdasan Dan Kesehatanmu (Pengarub Irama Bacaan Al-Qur'an Untuk Meningkatkan Daya Ingat Dan Daya Tahan Tubub) (Yogyakarta: DIVA Press, 2016), 91.

${ }^{6}$ Aina Mas Rurin, "Resepsi Alquran dalam Tradisi Pesantren di Indonesia (Studi Kajian Nagham Alquran di Pondok Pesantren Tarbitayul Quran Ngadiluweh Kediri)," Al-Bayan: Jurnal Studi Ilmu Al-Qur'an dan Tafsir 3, no. 2 (2018): 101-18, doi:10.15575/al-bayan.v3i2.3202. 
dan tilawah mujawwad. Menurut Michael Frishkopf perbedaan murattal dan tilawah Al-Qur'an terletak pada segi timbre (warna suara), ekspresi, melodi, modulasi, aksen, pause (jeda), pengulangan bacaan dan sebagainya.

Stimulus audiotori melalui resitasi bacaan Al-Qur'an baik itu dalam bentuk murattal (tadarrus) maupun tilawah dalam berbagai penelitian sebelumnya mampu meningkatkan daya tahan konsentrasi sehingga membuat aktivitas berpikir dan belajar menjadi maksimal. Menurut penelitian Shekha, $\mathrm{dkk}^{8}$ bahwa mendengarkan lantunan ayat Al-Qur'an dapat membangkitkan gelombang alfa pada otak dan membantu seseorang untuk mencapai kondisi rileks. Data ini diperoleh menggunakan alat ukur berupa electroencephalogram. Hasil yang sama juga diperoleh dengan mendengarkan musik namun apabila dibandingkan maka mendengarkan Al-Qur'an memiliki hasil yang jauh lebih baik. Sementara itu Monique ${ }^{9}$ dalam penelitiannya menyatakan bahwa terdapat perbedaan perkembangan kognitif pada sebelum dan sesudah terapi murattal dan musik klasik pada anak autis. Terdapat peningkatan kemampuan verbal, mengigat dan memahami pada sampel setelah diberikan treatment. Selain itu penelitian yang dilakukan oleh Julianto, $\mathrm{dkk}^{10}$ juga semakin menunjukkan hasil yang mendukung kemukjizatan Al-Qur'an dimana hasil penelitiannya menunjukkan bahwa Treatment mendengarkan murattal Al-Qur'an dengan durasi selama 30 menit mampu memberikan pengaruh yang signifikan terhadap peningkatan kemampuan konsentrasi.

Penelitian yang dipaparkan dalam artikel ini berbeda dengan penelitian sebelumnya. Pada artikel ini memaparkan pengaruh penggunaan audio AlQur'an yang disajikan dalam bentuk gaya bacaan murattal maupun tilawah mujawwad dalam proses pembelajaran Biologi terhadap kemampuan konsentrasi belajar mahasiswa tanpa memandang Al-Qur'an dari dimensi informatif yang fokusnya pada aktivitas yang berhubungan dengan menggali pengetahuan atau informasi dari Al-Qur'an. Variabel penelitian yang peneliti angkat juga memiliki spesifikasi yang berbeda dari penelitian sebelumnya dimana penelitian sebelumnya belum pernah membandingkan pengaruh mendengarkan murattal

${ }^{7}$ Michael Frishkopf, "Mediated Qur'anic Recitation and the Contestation of Islam in Contemporary Egypt," in Music and the Play of Power in the Middle East, North Africa and Central Asia (SOAS Studies in Music), ed. Laudan Nooshin (London: Ashgate, 2009), 86-87.

${ }^{8}$ Mudhir S. Shekha Abdullah O. Hassan Safin A. Othman, "Effects of Quran Listening and Music on Electroencephalogram Brain Waves," The Egyptian Journal of Experimental Biology (Zoology) 9, no. 1 (2013): 119-21.

9 Silvia Rizka Moniqe, "Efektifitas Terapi Musik Klasik Dan Murottal Terhadap Perkembangan Kognitif Anak Autis Di Sekolah Khusus Autis Garegeh Bukittinggi Tahun 2016," Journal of Engineering and Health Sciences 1, no. 1 (2017): 1-14.

${ }^{10}$ Julianto, Dzulqaidah, and Salsabila, "Pengaruh Mendengarkan Murattal Al Quran Terhadap Peningkatan Kemampuan Konsentrasi.". 
Al-Qur'an dan tilawah Al-Qur'an terhadap peningkatan kemampuan konsentrasi belajar dalam bidang studi Biologi.

Jenis penelitian yang dilakukan oleh peneliti merupakan penelitian komparatif dengan pendekatan ekperimental menggunakan desain two group pre and post test design. Tekhnik pengambilan sampel menggunakan Multi Stage Random Sampling (MSRS) dengan jumlah sampel sebanyak 15 orang pada masing-masing kelas eksperimen. Kemampuan konsentrasi belajar yang dimaksud dalam penelitian ini adalah konsentrasi verbal, konsentrasi visual, Konsentrasi dalam mengingat (memory), dan konsentrasi dalam memproduksi kata (word fluency). Konsentrasi belajar pada penelitian ini diukur setelah membaca materi ajar struktur dan fungsi sel. Instrumen pengumpulan data menggunakan tes kemampuan konsentrasi belajar yang dapat mengukur beberapa aspek diantaranya untuk dapat melihat konsentrasi yang menetap, memori, mengingat kata yang telah dipelajari dan sebagai tanda ketahanan konsentrasi. Instrument ini dikembangkan dan dirujuk dari tes Employee Aptitude Survey (EAS). Adapun Audio murattal dan tilawah yang digunakan pada penelitian ini adalah rekaman bacaan Al-Qur'an surah Al-Fajr.

\section{Pembahasan}

Hasil analisis deskriptif penelitian menunjukkan adanya peningkatan skor kemampuan konsentrasi belajar setelah pemberian intervensi audio murattal Al-Qur'an dan audio tilawah Al-Qur'an pada subjek penelitian.

Tabel 1: Data Statistik Deskriptif Skor Pretest Dan Posttest Kemampuan Konsentrasi Belajar Kelas Eksperimen 1 dan Eksperimen 2

\begin{tabular}{lllll}
\hline \multirow{2}{*}{ Data Statistik } & \multicolumn{2}{l}{$\begin{array}{l}\text { Eksperimen 1 } \\
\text { Intervensi Audio } \\
\text { Murattal Al-Qur'an }\end{array}$} & $\begin{array}{l}\text { Eksperimen 2 } \\
\text { Intervensi Audio } \\
\text { Tilawah Al-Qur'an }\end{array}$ \\
\cline { 2 - 5 } & Pretest & Posttest & Pretest & Posttest \\
\hline Jumlah Sampel & 15 & 15 & 15 & 15 \\
Nilai minimum & 37 & 70 & 25 & 52 \\
Nilai maksimum & 65 & 83 & 68 & 85 \\
Nilai rata-rata & 53,66 & 75,26 & 42,20 & 69,06 \\
Standar deviasi & 8,11 & 4,21 & 10,70 & 8,15 \\
Varians & 65,77 & 17,72 & 114,49 & 66,42 \\
Koefisien Varians & $15,11 \%$ & $5.59 \%$ & $25,35 \%$ & $11,80 \%$ \\
\hline
\end{tabular}


Berdasarkan hasil pretest dan posttest pada kelas eksperimen 1 diperoleh skor kemampuan konsentrasi belajar pada materi struktur dan fungsi sel yang meningkat setelah dilakukan perlakuan yaitu nilai rata-rata pretest adalah 53,66 dan posttest adalah 75,26 dengan peningkatan sebesar 21,60 sementara pada kelas eksperimen 2 diperoleh skor kemampuan konsentrasi belajar yang juga meningkat setelah dilakukan perlakuan yaitu nilai rata-rata pretest adalah 42,20 dan posttest adalah 69,06 dengan peningkatan sebesar 26,86. Jika dibandingkan maka peningkatan skor yang lebih besar terjadi pada kelas eksperimen 2 yang menggunakan intervensi audio tilawah Al-Qur'an.

Tabel 2: Perbandingan Rata-Rata Peningkatan Skor Pretest dan Postest

\begin{tabular}{cc}
\hline Variabel & Peningkatan \\
\hline Murattal Al-Quran & 21,60 \\
Tilawah Al-Qur'an & 26,86 \\
\hline
\end{tabular}

Sebelum melakukan pengujian menggunakan statistic inferesial, maka dilakukan uji normalitas dan uji homogenitas terlebih dahulu. Pengujian normalitas bertujuan untuk menyatakan apakah data skor kemampuan konsentrasi belajar pada pokok bahasan struktur dan fungsi sel untuk masingmasing kelas eksperimen 1 dan kelas eksperimen 2 dari populasi berdistribusi normal. Berdasarkan hasil analisis Kolmogorof-Smirnov Test, data pretest dan posttest untuk kelas eksperimen 1 dan eksperimen 2 menunjukkan data terdistribusi normal.

Tabel 3: Uji Normalitas

\begin{tabular}{ll}
\hline Pretest Kelas Eksperimen 1 & $\mathbf{0 , 2 0 0}$ \\
Posttest Kelas Eksperimen 1 & $\mathbf{0 , 2 0 0}$ \\
Pretest Kelas Eksperimen 2 & $\mathbf{0 , 2 0 0}$ \\
Posttest Kelas Eksperimen 2 & $\mathbf{0 , 1 9 8}$ \\
\hline
\end{tabular}

Pengujian homogenitas bertujuan untuk menyatakan apakah data skor kemampuan konsentrasi belajar pada pokok bahasan struktur dan fungsi sel untuk masing-masing kelas eksperimen 1 dan kelas eksperimen 2 berasal dari populasi yang homogen. Berdasarkan perhitungan menunjukkan bahwa kedua kelompok eksperimen memiliki data skor kemampuan konsentrasi yang homogen.

Tabel 4 : Uji Homogenitas

\begin{tabular}{|c|c|c|c|}
\hline Variabel & $\mathrm{F}_{\text {hitung }}$ & $\mathrm{F}_{\text {tabel } \alpha(0,05)}$ & Keterangan \\
\hline $\begin{array}{c}\text { Kemampuan Awal } \\
\text { (Initial Position) } \\
\text { Kelas Eksperimen } \\
1 \text { dan 2 }\end{array}$ & 1,74 & 2,48 & Homogen \\
\hline
\end{tabular}


Uji hipotesis dilakukan untuk mengetahui apakah kemampuan konsentrasi belajar mahasiswa pada kelas eksperimen 1 yang menggunakan intervensi audio murattal $\mathrm{Al}$-Qur'an pada proses pembelajaran berbeda dengan kemampuan konsentrasi belajar pada kelas eksperimen 2 yang menggunakan intervensi audio tilawah Al-Qur'an pada proses pembelajaran. Hasil analisis independent sample t-test dengan menggunakan program IBM SPSS versi 21 for Windows menunjukkan nilai $\mathrm{F}$ sebesar 1,638 dengan $p$-value $=0,018<0,05$, artinya nilai signifikansi lebih besar dari taraf kesalahan. Dengan demikian dapat disimpulkan bahwa terdapat perbedaan kemampuan konsentrasi belajar yang signifikan antara mahasiswa yang diperdengarkan murattal Al-Qur'an dengan mahasiswa yang diperdengarkan tilawah Al-Qur'an.

Tabel 5 : Uji Hipotesis

\begin{tabular}{|c|c|c|c|c|c|}
\hline \multirow{2}{*}{$\begin{array}{c}\text { Kemampuan } \\
\text { Konsentrasi } \\
\text { Belajar }\end{array}$} & \multicolumn{2}{|c|}{$\begin{array}{c}\text { Levene's Test } \\
\text { for Equality of } \\
\text { Variances }\end{array}$} & \multicolumn{4}{|c|}{ t-test for Equality of Means } \\
\cline { 2 - 7 } & $\mathrm{F}$ & Sig. & $\mathrm{t}$ & $\mathrm{df}$ & Sig. (2-tailed) \\
\hline $\begin{array}{c}\text { Equal variances } \\
\text { assumed } \\
\begin{array}{c}\text { Equal variances } \\
\text { not assumed }\end{array}\end{array}$ & 1.638 & .211 & 2.523 & 28 & .018 \\
\hline
\end{tabular}

\section{Gambaran Kemampuan Konsentrasi Belajar Mahasiswa Pendidikan Biologi yang diperdengarkan Murattal Al-Qur'an}

Al-Qur'an merupakan penawar dari langit yang bermanfaat dan mujarab untuk menyingkirkan penyakit. Hal ini sesuai firman Allah dalam QS Fussilat/41: 44: 


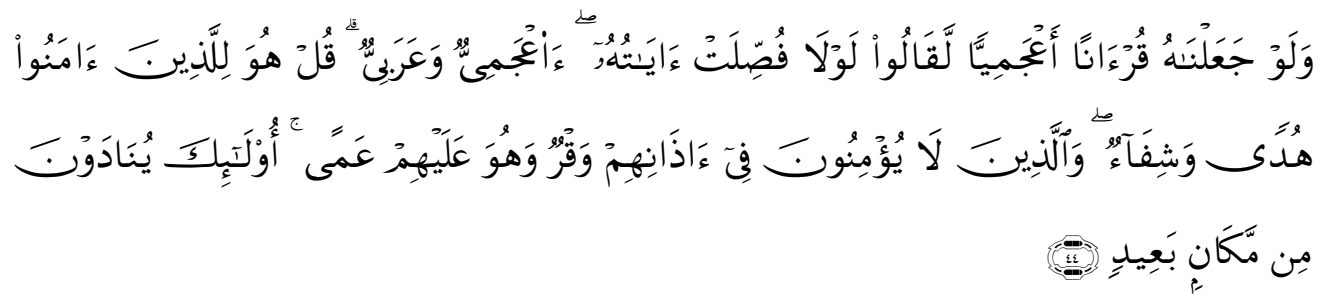

Dan jikealau kami jadikan Al-Qur'an itu suatu bacaan selain arab,tentulab mereka mengatakan mengapa tidak dijelaskan ayat-ayatnya? Apakah patut Al-Qur'an dalam bahasa asing sedang rasul adalah orang arab? Katakanlah "Al-Qur'an itu adalah petunjuk. dan obat (penawar) bagi orang-orang mu'min, sedangkan orang-orang yang tidak beriman pada telinga mereka ada sumbatan,dan Al-Qur'an itu suatu kegelapan bagi mereka.mereka itu adalab seperti yang dipanggil dari tempat yang jauh.

Al-Qur'an memberikan efek positif yang bersifat fisiologis bagi pembaca dan pendengarnya. Pada setiap agama terdapat tradisi yang sama yaitu tradisi recital (membaca) kitab suci baik sebagai kegiatan individu maupun kegiatan sosial yang melibatkan banyak orang. Secara umum mereka merasakan ketenangan jiwa, penurunan tingkat depresi dan kecemasan serta kesedihan. Dalam islam tradisi recital ini disebut tilawah, baik secara murattal, ritmik, yang kerap disebut "tartilan" atau qiraah murattalah. ${ }^{11}$

Menurut Sa'dullah murattal adalah suara ayat-ayat Al-Qur'an yang dibacakan atau dilagukan oleh seorang qori' secara tartil dan sesuai dengan kaidah tajwid. ${ }^{12}$ Suara Al-Qur'an merupakan suara yang memiliki ketukan dan gelombang tertentu yang dapat masuk dan menyebar kedalam tubuh kemudian bervibrasi sehingga mempengaruhi fungsi gerak sel otak dan membuat keseimbangan di dalam-nya. Hidayarti mengemukakan bahwa murattal adalah salah satu alunan musik yang memberikan pengaruh positif bagi pendengarnya. Purna menambahkan bahwa murattal adalah rekaman suara Al-Qur'an yang dibacakan dan dilagukan oleh seorang pembaca Al-Qur'an (qori'). Kemudian Ernawati menjelaskan bahwa murattal adalah rekaman suara Al-Qur'an seorang qori' yang dilagukan. ${ }^{13}$ Menurut fitriyani yaqub mendengarkan murattal AlQur'an dapat memunculkan gelombang delta di daerah frontal otak sebagai pusat intelektual dan pengatur emosi. ${ }^{14}$

${ }^{11}$ Abd Moqsith Ghazal, Luthfi Assyaukanie, and Ulil Abshar-Abdalla, Metodologi Studi AlQuran (Jakarta: Gramedia Pustaka Utama, 2009), 39.

${ }^{12}$ Fitriyani Yaqub, "Meminimalisir Perilaku Hiperaktif Impulsif Anak Autis Melalui Intervensi Program Audio Murattal” (Thesis, UNESA, 2016), 18.

${ }^{13}$ Azmul Fuady Idham and Andi Ahmad Ridha, "Apakah Mendengarkan Murrotal AlQuran Dapat Menurunkan Kecemasan Akademik Pada Mahasiswa?," JIP Jurnal Intervensi Psikologi) 9, no. 2 (December 1, 2017): 141-54, doi:10.20885/intervensipsikologi.vol9.iss2.art1.

${ }^{14}$ Yaqub, "Meminimalisir Perilaku Hiperaktif Impulsif," 19. 
Pada penelitian ini Peneliti melakukan pengujian analisis statistik deskriptif untuk memperoleh gambaran mengenai efek dari mendengarkan murattal Al-Qur'an berupa kemampuan konsentrasi pada mahasiswa pendidikan Biologi sehingga diperoleh hasil pretest dengan rata-rata skor sebesar 53,66 sementara pada postest diperoleh rata-rata skor sebesar 75,26 dan peningkatan sebesar 21,60. Adapun prosedur penelitian yang dilakukan oleh peneliti yaitu subjek penelitian diminta untuk membaca resume naskah bahan ajar terkait struktur dan fungsi sel yang telah disiapkan oleh peneliti dan telah melalui proses validasi oleh validator ahli. Proses belajar tersebut yang meliputi tahap perhatian (attention phase) dan tahap penyimpanan dalam ingatan (retention phase) dilakukan selama 20 menit. Setelah itu subjek penelitian diberikan pretest berupa tes kemampuan konsentrasi belajar yang terdiri atas 5 subtes yaitu subtes word fluency untuk mengukur konsentrasi dalam kelancaran memproduksi kata/istilah pada pokok bahasan struktur dan fungsi sel, subtes verbal comprehension "synonym" untuk mengukur konsentrasi verbal dalam memenemukan padanan kata/istilah pada pokok bahasan struktur dan fungsi sel, subtes verbal classification untuk mengukur konsentrasi verbal dalam mengklasifikasikan kata/istilah pada pokok bahasan struktur dan fungsi sel, subtes visual speed and accurate untuk mengukur konsentrasi visual berupa kecepatan dan ketelitian dalam melihat dan mengamati gambar pada pokok bahasan struktur dan fungsi sel, dan terakhir subtes understanding of reading untuk mengukur konsentrasi dalam mengingat, memahami, menemukan, dan menyaring informasi pada pokok bahasan struktur dan fungsi sel. Setelah itu treatment untuk mengkondisikan iklim kelas dalam suasana yang rileks dan mengkondisikan gelombang otak pada zona alfa dilakukan dengan memutarkan murattal Al-Qur'an surah Al-Fajr dengan menggunakan loud speaker selama 10 menit kemudian prosedur yang sama diulangi yaitu tahap perhatian (attention phase) dan tahap penyimpanan dalam ingatan (retention phase) dengan membaca resume naskah struktur dan fungsi sel selama 20 menit. Proses ini dilakukan sambil diiringi dengan murattal Al-Qur'an kemudian melakukan pengukuran kembali untuk mengetahui skor akhir kemampuan konsentrasi belajar mahasiswa setelah diberikan treatment.

Rancangan pretest dan posttest pada penelitian ini digunakan untuk menguji efek suatu perlakuan terhadap variabel dependen dalam hal ini yaitu kemampuan konsentrasi belajar. Pengujian dilakukan dengan membandingkan hasil pretest dan posttest skor kemampuan konsentrasi belajar. Pretest menginformasikan kemampuan awal (initial position) para subjek sebelum dilakukan treatment. Apabila skor posttest lebih besar dari pretest maka dapat disimpulkan bahwa mendengarkan murattal Al-Qur'an memiliki pengaruh terhadap peningkatan kemampuan konsentrasi belajar. 
Berdasarkan data analisis statistik deskriptif dapat dilihat bahwa skor posttest dengan intervensi audio murattal Al-Qur'an lebih besar dari pretest sehingga intervensi audio murattal Al-Qur'an tergolong baik dalam meningkatkan kemampuan konsentrasi belajar. Kemampuan dalam berkonsentrasi akan mempengaruhi kecepatan dalam menangkap informasi atau materi yang diberikan. Didapatkan bahwa seluruh subjek mengalami peningkatan skor kemampuan konsentrasi setelah diadakan treatment.

Hasil dari penelitian ini sesuai dengan teori yang diungkapkan oleh Fitriyani Yaqub bahwa murattal yang diperdengarkan dengan tempo yang lambat serta harmonis dapat mengaktifkan hormone endorphin alami, menurunkan hormone-hormon stress, dan memperbaiki sistem kimia tubuh serta meningkatkan perasaan rileks, mengalihkan perhatian dari rasa cemas, takut, dan tegang ${ }^{15}$ sehinngga bermuara pada peningkatan kemampuan konsentrasi. Hasil penelitian ini didukung oleh penelitian yang dilakukan oleh Very Julianto, Rizki Putri Dzulqaidah dan Siti Nurina Salsabila dengan judul Pengaruh Mendengarkan Murattal Al-Qur'an terbadap Peningkatan Kemampuan Konsentrasi. Data dikumpulkan dengan menggunakan instrumen tes digit span forward and backward dari subtes wechsler intelegensi scale dengan nilai rata-rata pretest sebesar 10,4 dan nilai rata-rata posttest sebesar 11,2 sehingga dapat disimpulkan bahwa mendengarkan murattal Al-Qur'an memberikan pengaruh yang signifikan terhadap peningkatan kemampuan konsentrasi. ${ }^{16}$

Murattal bekerja pada otak dimana ketika terjadi rangsangan dari mendengarkan audio murattal maka otak akan memproduksi zat kimia yang disebut zat neuropeoptide. Molekul ini akan menyangkut kedalam reseptorreseptor dan memberikan umpan balik berupa kenyamanan atau kenikmatan. ${ }^{17}$ Menurut Alhoseini diketahui bahwa mendengarkan murattal Al-Qur'an mampu memberikan perasaan lega dan rileks serta membawa ketenangan dalam hati. Berdasarkan uji atau penggunaan EEG untuk mengidentifikasi emosi pada saat seseorang mendengarkan murattal Al-Qur'an Menunjukkan nilai alpha band sebesar 8-13 Hz. Hasil EEG menunjukkan terjadinya peningkatan pada alpha band sebelum dan sesudah mendengarkan Al-Qur'an. ${ }^{18}$

Penelitian lain dilakukan oleh Rani menunjukkn bahwa resitasi AlQur'an yang ritmis mampu mendatangkan tanggapan theta yang lebih mudah di

${ }^{15}$ Ibid., 19-20.

${ }^{16}$ Julianto, Dzulqaidah, and Salsabila, "Pengaruh Mendengarkan Murattal Al Quran Terhadap Peningkatan Kemampuan Konsentrasi."

${ }^{17}$ Abdurrochman A, Perdana S, and Andhika S, "Muratal Al Quran : Alternatif Terapi Suara Baru," in Seminar Sains Dan Teknologi-II (Lampung, 2008).

${ }^{18}$ Amjad M.R. Alzeer Alhouseini et al., "Stress Assessment While Listening to Quran Recitation," in 2014 International Conference on Computer Assisted System in Health, 2014, 67-72, doi:10.1109/CASH.2014.14. 
otak manusia dibandingkan dengan ritme non Al-Qur'an. Al-Qur'an merupakan salah satu alternatif atau metode dalam sound theraphy (terapi suara) yang dapat menimbulkan efek menenangkan terhadap pendengar. ${ }^{19}$ Hal tersebut dijustifikasi oleh firman Allah swt dalam QS Ar-Rad/13: 28 yang mendeskripsikan manfaat membaca Al-Qur'an untuk menciptakan kondisi yang menenangkan. ${ }^{20}$

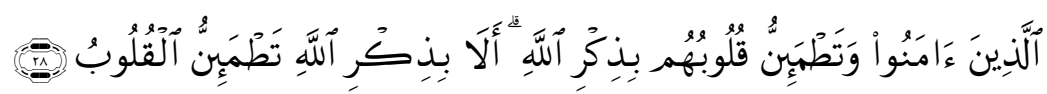

(Yaitu) orang-orang yang beriman dan hati mereka manjadi tenteram dengan mengingat Allah. Ingatlah, hanya dengan mengingati Allah-lah hati menjadi tenteram.

Kemampuan subjek dalam menjawab tes dengan tepat dan benar pada penelitian ini dapat terjadi karena subjek dapat berkonsentrasi lebih lama dari sebelumnya setelah diberikan treatment intervensi murattal Al-Qur'an sehingga dapat fokus pada informasi yang dibutuhkan serta dapat menyaring secara langsung informasi yang tidak relevan. Ini diyakini karena kematangan neurologis dan kesadaran beragama secara mapan sehingga treatment intervensi murattal Al-Qur'an dapat berpengaruh dengan baik.

Konsentrasi belajar tidak datang dengan sendirinya atau dari pembawaan bakat seseorang sejak lahir. Konsentrasi belajar akan timbul dengan penciptaan dan perencanaan yang kemudian dijadikan kebiasaan dalam belajar, sementara intervensi murattal Al-Qur'an merupakan salah satu metode yang cocok untuk meningkatkan konsentrasi belajar pada pembelajar.

Murattal Al-Qur'an memiliki melodi yang menarik dan mempesona, makna ungkapan yang kuat, serta artikulasi yang jelas yang dapat mempengaruhi orang yang mendengarkannya. ${ }^{21}$ Aktivitas membaca maupun mendengarkan murattal Al-Qur'an dapat mempengaruhi sistem otak kita baik korteks yang merupakan pusat kecerdasan maupun sistem limbik yang merupakan pusat emosi sehingga dapat dikatakan bahwa kegiatan mendengarkan murattal $\mathrm{Al}$ Qur'an mampu membawa dampak yang positif bagi kecerdasan dan emosi pembacanya. ${ }^{22}$ Dengan begitu maka mendengarkan audio murattal Al-Qur'an

${ }^{19}$ Nur Syairah Ab Rani et al., "Brainwave Theta Signal Responses During Receptive Auditory Quranic and Non-QuranicStimulation: A Pilot Study," in Proceedings of Universiti Sains Malaysia International Conference on Social Sciences (Malaysia, 2015), 262-69.

${ }^{20}$ Aizid, Tartil Al-Qur'an Untuk Kecerdasan Dan Kesehatanmu, 91.

${ }^{21} \mathrm{H}$ Sadeghi, "Voice of Quran and Health: A Review of Performed Studies in Iran," Quran \& Medicine 1, no. 1 (2011): 33-37.

${ }^{22}$ Mustamir Pedak, Quran For Gen, Mukjizat Terapi Quran Untuk Hidup Sukses (Jakarta: PT Wahyu Media, 2009), 56. 
dapat dijadikan sebagai salah satu alternatif untuk peningkatan kemampuan kognitif dan daya tahan konsentrasi.

\section{Gambaran Kemampuan Konsentrasi Belajar Mahasiswa Pendidikan Biologi yang diperdengarkan Tilawah Al-Qur'an}

Salah satu aktivitas membaca Al-Qur'an yang menarik adalah pembacaan disertai bunyi nada dan irama. Seni membaca Al-Qur'an yang disertai dengan lagu atau langgam merupakan salah satu bentuk kebudayaan islam yang mempresentasikan bagaimana $\mathrm{Al}-\mathrm{Qur}$ 'an ditransformasikan dalam bentuk lisan melalui lagu. ${ }^{23} \mathrm{Hal}$ ini diatur dalam ilmu yang disebut sebagai ilmu nagham.

Nagham berarti bunyi kalimat dan keindahan suara ketika membaca. ${ }^{24}$ Ahli bahasa mendefinisikan nagham sebagai bergetarnya sendi-sendi dengan keras yang menyebabkan tersentuhnya hati. ${ }^{25}$ Nagham bisa juga disebut sebagai lagu atau melodi yang berfokus pada vocal suara indah tunggal tanpa diiringi alat musik, tidak terikat dengan not balok, dan hanya digunakan untuk memperindah bacaan Al-Qur'an. Jika nagham diibaratkan sebagai proses maka keindahan adalah hasilnya sedangkan objeknya dalam hal ini adalah Al-Qur'an. Bernagham berbeda dengan bermusik karena hanya merupakan handasah al-shaut (tekhnik suara) saja. ${ }^{26}$ Ada lebih dari 50 lagu (maqam) dalam etnomusikologi arab yang tidak hanya dipergunakan untuk mengalunkan ayat-ayat Al-Qur'an saja tetapi juga syair-syair arab yang masyhur. Dari sekian banyak lagu, ada tujuh lagu yang dianggap sebagai jendela lagu Al-Qur'an yang diantaranya ada yang memiliki karakteristik sedih dan ada pula yang memiliki karakter halus dan lembut. Tujuh lagu yang dimaksud adalah lagu bayyati, hijaz, saba', rast, nahawand, sika, dan jiharkah. Setiap lagu tersebut merupakan jembatan antara resitasi Al-Qur'an dan musik sekuler. ${ }^{27}$

Pada penelitian ini peneliti melakukan pengujian analisis statistik deskriptif untuk memperoleh gambaran konsentrasi belajar mahasiswa yang diberikan intervensi audio tilawah Al-Qur,an dan diperoleh hasil pretest dengan rata-rata skor sebesar 42,20 sementara pada postest diperoleh rata-rata skor sebesar 69,06 dan peningkatan sebesar 26,86.

Prosedur penelitian pada kelas eksperimen 2 (intervensi audio tilawah Al-Qur'an) sama dengan prosedur penelitian yang dilakukan pada kelas

${ }^{23}$ Rurin, "Resepsi Alquran dalam Tradisi Pesantren di Indonesia," 102.

${ }^{24} \mathrm{Abu}$ al-Husain Ahmad Ibn Faris, Mu'jam Maqayis al-Lughah (Beirut: Dar Al-Fikr, 1994), 452.

${ }^{25}$ Jamaluddin Abi al-Fadl Ibn Mukrim Ibn Mandzur, Lisan Al-Arab (Beirut: Dar Al-kutub Al-Ilmiyah, 2003), 449.

${ }^{26}$ Kristina Nelson, "Reciter and Listener: Some Factors Shaping the Mujawwad Style of Qur'anic Reciting," Ethnomusicology 26, no. 1 (1982): 41-47, doi:10.2307/851400.

${ }^{27}$ Ibid. 
eksperimen 1 (intervensi audio murattal Al-Qur'an). Pengujian dilakukan dengan membandingkan hasil pretest dan posttest skor kemampuan konsentrasi belajar. Berdasarkan data analisis statistik deskriptif dapat dilihat bahwa skor posttest dengan intervensi audio tilawah $\mathrm{Al}$-Qur'an lebih besar dari pretest sehingga intervensi audio tilawah Al-Qur'an tergolong baik dalam meningkatkan kemampuan konsentrasi belajar.

Hasil dari penelitian ini sesuai dengan teori yang diungkapkan oleh Oken yang menyatakan bahwa efek suara dapat memengaruhi kesuluruhan fisiologis tubuh pada basis aktivasi korteks sensori dengan aktivitas sekunder lebih lama pada neokorteks dan beruntun ke dalam sistem limbik, hipotalamus, dan sistem saraf otonom. Para ahli terapi suara menyatakan saraf vagus dan sistem limbik (bagian otak yang bertanggung jawab untuk emosi) merupakan penghubung antara telinga, otak dan sistem saraf otonom yang menjelaskan bagaimana suara bekerja dalam menciptakan kondisi yang rileks. ${ }^{28} \mathrm{Hal}$ ini didukung oleh Penelitian yang dilakukan oleh Mudhir S. Shekha, Abdullah O. Hassan dan Safiin A.Othman dengan judul Effect of Quran Listening and Music on Electroencephalogram Brain Waves. Hasil penelitian tersebut menunjukkan bahwa mendengarkan lantunan ayat Al-Qur'an dapat membangkitkan gelombang alfa pada otak dan membantu seseorang untuk mencapai kondisi rileks. ${ }^{29}$

Berdasarkan kerangka konsep yang dijelaskan di atas terkait efek suara terhadap kondisi fisiologis dan psikis maka intervensi audio tilawah Al-Qur'an dalam meningkatkan kemampuan konsentrasi belajar dapat kita generalisasi memiliki pengaruh yang relatif sama dengan intervensi audio murattal AlQur'an. Hal ini juga didukung oleh hasil penelitian Dr Ahmad al-Qadhi yang menyatakan bahwa mendengarkan ayat suci Al-Qur'an memiliki pengaruh yang signifikan dalam menurunkan ketegangan urat syaraf reflektif ${ }^{30}$ baik itu dengan gaya bacaan murattal maupun tilawah.

Kondisi rileks yang dibangun oleh intervensi audio tilawah Al-Qur'an erat kaitannya dengan kemampuan konsentrasi mahasiswa sebab konsentrasi merupakan keadaan pikiran yang diaktifkan oleh sensasi didalam tubuh, Syarat untuk mengaktifkan sensasi tersebut diperlukan keadaan yang rileks dan suasana yang tenang agar seseorang dapat menggunakan otaknya dengan maksimal dan dapat meningkatkan konsentrasinya. salah satu treatment untuk merangsang terciptanya sensasi ini adalah melalui intervensi audio tilawah Al-Qur'an.

${ }^{28}$ Joseph I. Sirven, "Complementary Therapies in Neurology: An Evidence Based Approach,” Neurology ${ }^{\circledR}$ 67, no. 6 (2006), doi:10.1212/01.wnl.0000189103.16640.0b.

${ }^{29}$ Othman, "Effects of Quran Listening and Music," 119-21.

${ }^{30}$ Septian el Syakir, Islamic Hypnoparenting: Mendidik Anak Masa Kini Ala Rasulullah (Jakarta: Kawan Pustaka, 2014), 43. 
Mendengarkan lantunan ayat Al-Qur'an dengan lagu yang indah terbukti dapat membuat sesorang menjadi rileks dan dapat memaksimalkan kerja otaknya untuk fokus dan memusatkan perhatiannya pada suatu objek yang sedang dipelajari. Menurut Sa'dullah Al-Qur'an juga memiliki banyak manfaat bagi pembaca maupun pendengar salah satunya terhadap perkembangan kognitif yaitu dapat mempertajam ingatan dan pemikiran yang cemerlang. ${ }^{31}$

\section{Perbandingan Kemampuan Konsentrasi Belajar Antara Mahasiswa yang diperdengarkan Murattal Al-Qur'an Dengan Tilawah Al-Qur'an}

Hasil uji hipotesis perbedaan antara nilai posttest kelas eksperimen 1(murattal Al-Qur'an) dan kelas eksperimen 2 (tilawah AlQur'an) menggunakan analisis independent sample t-test diperoleh hasil sig.(2-tailed) sebesar 0,018 dengan nilai $\alpha=0$,05. Ini menunjukkan sig.(2-tailed) $<\alpha$ sehingga dapat disimpulkan bahwa $\mathrm{H}_{0}$ ditolak dan $\mathrm{H}_{1}$ diterima yang berarti bahwa terdapat perbedaan skor kemampuan konsentrasi belajar antara mahasiswa yang diajar menggunakan intervensi audio murattal Al-Qur'an dengan mahasiswa yang diajar menggunakan intervensi audio tilawah Al-Qur'an. Hasil pretest dan posttest menunjukkan bahwa penggunaan audio murattal Al-Qur'an dan audio tilawah Al-Qur'an masing-masing dapat meningkatkan skor kemampuan konsentrasi belajar mahasiswa pada kedua kelas tersebut. Akan tetapi, dari data statistik tersebut penggunaan audio tilawah Al-Qur'an lebih efektif digunakan untuk meningkatkan kemampuan konsentrasi belajar khususnya pada pokok bahasan struktur dan fungsi sel sebab memiliki selisih skor pretest dan posttest yang lebih besar dibandingkan dengan murattal Al-Qur'an. Hal ini sangat mungkin terjadi karena tilawah Al-Qur'an memiliki melodi yang lebih indah dan karakter yang relatif lebih bergairah dan membangkitkan semangat dibandingkan murattal AlQur'an.

Selain itu, Perbedaan skor kemampuan konsentrasi belajar ini dapat terjadi karena beberapa faktor, diantaranya emosi/sensasi tertentu yang dibangkitkan oleh jenis gaya bacaan $\mathrm{Al}$-Qur'an tertentu, perbedaan preferensi atau selera mahasiswa terhadap jenis gaya bacaan Al-Qur'an, dan pengetahuan mahasiswa sebelumnya mengenai topik yang dipelajari.

Gaya pembacaan Al-Qur'an dengan lantunan yang berbeda dapat menghasilkan perasaan yang berbeda dalam diri subjek penelitian, sebab genre/jenis bacaan yang berbeda dapat menyebabkan timbulnya emosi yang berbeda pula. Meskipun demikian taksonomi yang sistematis terhadap hubungan antara gaya pembacaan Al-Qur'an dan emosi tertentu belum bisa disusun secara pasti. Lebih jauh lagi bahwa tidak semua individu bereaksi emosional secara signifikan terhadap gaya pembacaan Al-Qur'an tertentu. oleh karena itu 2008), 36 .

${ }^{31}$ Sa'dulloh Sa'dulloh, 9 Cara Praktis Menghapal Al-Qur'an (Jakarta: Gema Insani Press, 
pengaruh mendengarkan bacaan Al-Qur'an dalam berbagai jenis gaya dalam membacanya terhadap emosi dan berbagai turunannya juga tidak dapat dimutlakkan sebab efeknya tergantung pada berbagai faktor misalnya karakter gaya bacaan Al-Qur'an, karakter pendengar, karakter penyajian, dan karakter kontekstual. Dalam kaitannya dengan hasil penelitian yang peneliti lakukan, kenyataan bahwa beberapa subjek penelitian kurang menyukai gaya bacaan tertentu atau alunan ayat Al-Qur'an itu sendiri sangat mungkin menyebabkan emosi negatif saat audio murattal atau tilawah Al-Qur'an diperdengarkan. Emosi negatif inilah yang menghalangi proses belajar serta sedikitnya berpengaruh terhadap kemampuan konsentrasi sehingga terjadi perbedaan skor posttest pada kedua kelas eksperimen. Selain itu walaupun rata-rata skor pretest dan posttest mengalami peningkatan secara signifikan namun masih ada beberapa subjek penelitian yang secara individual mengalami peningkatan skor kemampuan konsentrasi yang relatif rendah pada kedua kelas eksperimen. Hal ini sangat mungkin terjadi karena preferensi subjek penelitian terhadap murattal maupun tilawah Al-Qur'an yang kurang baik selain itu juga dapat disebabkan oleh lemahnya minat dan motivasi pada mahasiswa, bersifat pasif dalam belajar, dan tidak memiliki kecakapan dalam cara-cara belajar yang baik. Sebab menurut Winkel yang dikutip oleh Ely Manizar menyatakan bahwa aktivitas yang tidak didasari oleh motivasi yang kuat akan menimbulkan ketidakseriusan dan perhatian tidak optimal sehinnga menimbulkan dorongan untuk mengalihkan aktivitas tersebut ke aktivitas yang lain. ${ }^{32}$

Dengan demikian meskipun kerangka konsep yang dibangun oleh beberapa penelitian memperlihatkan bahwa belajar sambil mendengarkan murattal atau tilawah Al-Qur'an mampu meningkatkan kemampuan konsentrasi belajar namun hal ini kemungkinan besar tidak berlaku bagi semua orang. Efek positifnya adalah murattal atau tilawah Al-Qur'an dapat meningkatkan mood, semangat belajar dan menciptakan suasana rileks yang siap untuk belajar namun pada beberapa individu justru dapat menyebabkan bertambahnya beban kognitif terutama jika materi yang ingin dipelajari memuat informasi atau sesuatu yang baru. Murattal ataupun tilawah Al-Qur'an justru akan memiliki efek negatif berganda jika preferensi dan penerimaan subjek penelitian terhadap Al-Qur'an kurang baik.

Selain itu peneliti berpendapat bahwa tidak semua materi pelajaran akan memiliki hasil yang sama baiknya dengan yang telah dicapai oleh peneliti apabila diperdengarkan murattal atau tilawah Al-Qur'an. Hal ini tergantung tekhnik

32 Tri Sutasmi Nirwan, Muh Rapi, and Muchlisah Muchlisah, "Hubungan Antara Kesiapan Mental Dengan Motivasi Belajar Pada Mata Pelajaran Biologi," Jurnal Biotek 4, no. 1 (2016): 33-51, doi:10.24252/jb.v4i1.1771. 
berpikir yang dibutuhkan dalam mempelajari materi tersebut. Dalam kaitannya dengan penelitian yang dilakukan oleh peneliti, murattal dan tilawah Al-Qur'an sama-sama memiliki efek yang positif terhadap peningkatan kemampuan konsentrasi khususnya pada materi struktur dan fungsi sel.

Penggunaan intervensi perangsangan audiotori yang bervariasi untuk meningkatkan kemampuan konsentrasi belajar sangat dianjurkan karena akan bermuara pada kecepatan penerimaan dan penyerapan materi ajar serta berbanding lurus dengan hasil belajar. Baik penggunaan audio murattal AlQur'an maupun audio tilawah Al-Qur'an masing-masing memiliki keunggulan sehingga dapat mencapai skor kemampuan konsentrsi belajar yang baik. Mengenai pemilihan intervensi perangsangan audiotori yang lebih baik untuk meningkatkan kemampuan konsentrasi belajar, maka penggunaan audio tilawah Al-Qur'an lebih unggul dibandingkan dengan penggunaan audio murattal AlQur'an namun kedua media tersebut sama-sama mampu memberikan perubahan terhadap skor kemampuan konsentrasi belajar. Banyak hal yang perlu diperhatikan dalam menerapkan intervensi perangsangan audiotori untuk meningkatkan konsentrasi belajar, salah satunya ialah preferensi subjek penelitian terhadap media yang digunakan.

\section{Kesimpulan}

Penelitian ini telah menunjukkan adanya peningkatan skor kemampuan konsentrasi belajar mahasiswa pendidikan Biologi setelah mendengar murattal dan tilawah Al-Qur'an. Penelitian ini juga membuktikan bahwa terdapat pengaruh yang positif setelah mendengar murattal dan tilawah Al-Qur'an terhadap peningkatan kemampuan konsentrasi, meskipun masih terdapat faktor lain yang perlu diteliti karena ikut berpengaruh pada kemampuan konsentrasi tersebut, seperti inteligensi, minat dan motivasi belajar, dan iklim belajar, serta gaya belajar. Terdapat perbedaan yang signifikan peningkatan kemampuan konsentrasi antara mahasiswa yang diperdengarkan murattal Al-Qur'an dengan yang diperdengarkan tilawah Al-Quran dengan nilai sig.(2-tailed) $0,018<\alpha 0,05$. Perlakuan yang lebih efektif meningkatkan konsentrasi belajar adalah tilawah AlQur'an.

\section{Bibliografi}

A, Abdurrochman, Perdana S, and Andhika S. "Muratal Al Quran: Alternatif Terapi Suara Baru.” In Seminar Sains Dan Teknologi-II. Lampung, 2008.

Ab Rani, Nur Syairah, Muzaimi Mustapha, Faruque Reza, and Muhammad Amiri Ab Ghani. "Brainwave Theta Signal Responses During Receptive Auditory Quranic and Non-QuranicStimulation: A Pilot Study." In Proceedings of Universiti Sains Malaysia International Conference on Social Sciences. Malaysia, 2015. 
Aizid, Rizem. Tartil Al-Qur'an Untuk Kecerdasan Dan Kesehatanmu (Pengarub Irama Bacaan Al-Qur'an Untuk. Meningkatkan Daya Ingat Dan Daya Tahan Tubub). Yogyakarta: DIVA Press, 2016.

Alhouseini, Amjad M.R. Alzeer, Imad Fakhri Al-Shaikhli, Abdul Wahab bin Abdul Rahman, Khamis Alarabi, and Mariam Adawiah Dzulkifli. "Stress Assessment While Listening to Quran Recitation." In 2014 International Conference on Computer Assisted System in Health, 67-72, 2014. doi:10.1109/CASH.2014.14.

Chatib, Munif. Sekolahnya Manusia: Sekolah Berbasis Multipe Intelligences Di Indonesia. Bandung: Kaifa PT Mizan Pustaka, 2012.

Fauzan, Norsiah, and Nurul Amira Abidin. "The Effects of Neurotherapy (NFT) Using Ayatul Kursi as Stimulus on Memory Performance." Journal of Isamic, Social, Economic and Development 2, no. 4 (2017): 22-31.

Frishkopf, Michael. "Mediated Qur'anic Recitation and the Contestation of Islam in Contemporary Egypt." In Music and the Play of Power in the Middle East, North Africa and Central Asia (SOAS Studies in Music), edited by Laudan Nooshin. London: Ashgate, 2009.

Ghazal, Abd Moqsith, Luthfi Assyaukanie, and Ulil Abshar-Abdalla. Metodologi Studi Al-Quran. Jakarta: Gramedia Pustaka Utama, 2009.

Ibn Faris, Abu al-Husain Ahmad. Mu'jam Maqayis al-Lughah. Beirut: Dar Al-Fikr, 1994.

Ibn Mandzur, Jamaluddin Abi al-Fadl Ibn Mukrim. Lisan Al-Arab. Beirut: Dar Al-kutub Al-Ilmiyah, 2003.

Idham, Azmul Fuady, and Andi Ahmad Ridha. "Apakah Mendengarkan Murrotal Al-Quran Dapat Menurunkan Kecemasan Akademik Pada Mahasiswa?” JIP (Jurnal Intervensi Psikologi) 9, no. 2 (December 1, 2017): 141-54. doi:10.20885/intervensipsikologi.vol9.iss2.art1.

Julianto, Very, Rizki Putri Dzulqaidah, and Siti Nurina Salsabila. "Pengaruh Mendengarkan Murattal Al Quran Terhadap Peningkatan Kemampuan Konsentrasi." Psympathic: Jurnal Ilmiah Psikologi 1, no. 2 (2014): 120-29. doi:10.15575/psy.v1i2.473.

Moniqe, Silvia Rizka. "Efektifitas Terapi Musik Klasik Dan Murottal Terhadap Perkembangan Kognitif Anak Autis Di Sekolah Khusus Autis Garegeh Bukittinggi Tahun 2016." Journal of Engineering and Health Sciences 1, no. 1 (2017): 1-14. 
Nelson, Kristina. "Reciter and Listener: Some Factors Shaping the Mujawwad Style of Qur'anic Reciting." Ethnomusicology 26, no. 1 (1982): 41-47. doi: $10.2307 / 851400$.

Nirwan, Tri Sutasmi, Muh Rapi, and Muchlisah Muchlisah. "Hubungan Antara Kesiapan Mental Dengan Motivasi Belajar Pada Mata Pelajaran Biologi." Jurnal Biotek 4, no. 1 (2016): 33-51. doi:10.24252/jb.v4i1.1771.

Othman, Mudhir S. Shekha Abdullah O. Hassan Safin A. "Effects of Quran Listening and Music on Electroencephalogram Brain Waves." The Egytian Journal of Experimental Biology (Zoology) 9, no. 1 (2013): 119-21.

Pedak, Mustamir. Quran For Gen, Mukjizat Terapi Quran Untuk Hidup Sukses. Jakarta: PT Wahyu Media, 2009.

Rurin, Aina Mas. "Resepsi Alquran dalam Tradisi Pesantren di Indonesia (Studi Kajian Nagham Alquran di Pondok Pesantren Tarbitayul Quran Ngadiluweh Kediri)." Al-Bayan: Jurnal Studi Ilmu Al-Qur'an dan Tafsir 3, no. 2 (2018): 101-18. doi:10.15575/al-bayan.v3i2.3202.

Sadeghi, H. "Voice of Quran and Health: A Review of Performed Studies in Iran." Quran \& Medicine 1, no. 1 (2011): 33-37.

Sa'dulloh, Sa'dulloh. 9 Cara Praktis Menghapal Al-Qur'an. Jakarta: Gema Insani Press, 2008.

Sirven, Joseph I. "Complementary Therapies in Neurology: An Evidence Based Approach.” Neurology @ 67, no. 6 (2006). doi:10.1212/01.wnl.0000189103.16640.0b.

Syah, Muhibbin. Psikologi Belajar. Jakarta: Rajawali press, 2009.

Syakir, Septian el. Islamic Hypnoparenting: Mendidik Anak Masa Kini Ala Rasulullah. Jakarta: Kawan Pustaka, 2014.

Yaqub, Fitriyani. "Meminimalisir Perilaku Hiperaktif Impulsif Anak Autis Melalui Intervensi Program Audio Murattal.” Thesis, UNESA, 2016. 